\title{
Fish Marketing Status with Formalin Treatment in Bangladesh
}

\author{
Shatabdi Goon ${ }^{1}$, Munmun Shabnam Bipasha², Md.Saiful Islam ${ }^{3}$ \\ ${ }^{1}$ Nutrition and Food Engineering Department, Daffodil International University, Bnagladesh \\ ${ }^{2}$ Daffodil International University, Dhaka, Bangladesh \\ ${ }^{3}$ Bangladesh University of Health Sciences, Bangladesh
}

\begin{tabular}{l} 
Article Info \\
\hline Article history: \\
Received Mar 17, 2014 \\
Revised Apr 24, 2014 \\
Accepted May 24, 2014 \\
\hline Keyword: \\
Formalin \\
Fish marketing \\
Food safety \\
Public health \\
Economical impact
\end{tabular}

\begin{abstract}
Fish possess an extremely strong cultural attachment considering irreplaceable animal food source in Bangladeshi diet beset with nutritional importance. It has been getting endangered by abominable practice of formalin in marketing leaded by some deceitful traders counting profit beyond ethical attainment and endangering public health. This paper outlines the formalin extremity with a several years practice in fish marketing involving almost 5\% city markets with a petty heterogeneity comprising contrastive and potential strategy with formalin access. Regardless, this formalin corruption affiliated with deleterious health aggravations both for traders and consumers, comes out with impotency in workforce contravening economical influence on overall national prosperity.
\end{abstract}

Copyright (C) 2014 Institute of Advanced Engineering and Science. All rights reserved.

Corresponding Author:

Shatabdi Goon,

Nutrition and Food Engineering Department,

Daffodil International University, Dhaka, Bangladesh,

Shukrabad, Dhaka-1207, Bangladesh, Tel No: +8801711185574.

Email: shatabdigoon@yahoo.com

\section{INTRODUCTION}

Fish consumption has been a common practice by human since the pre historic era. It is important to highlight a key contribution that fish provides to human nutrition as well as the positive impact on health. It is an arrant fact that they received different emphasis both in developed countries and developing. For many developing country communities, especially those living close to coastal and inland waters, fish are the dominant food of animal source. In Bangladesh, 75\% of daily protein consumption comes from fish. Unfortunately, fish is no longer a favorite option for many city dwellers on their everyday menu, and also this as the sale of formalin-laced fish is considering the ultimate substance with a great preservative effect being able to kill microbes or germs without minimal cost, has become a rampant practice in the city's kitchen markets [1]. Once fish consumption has important implications in national food and nutrition security, providing more than $60 \%$ of animal protein [2], fishes dipped in formalin are harmful to health, leading to several health complications. Therefore, formalin laced fish consumption enervates disease prevention capacity in human promoting less productivity in workforce and thus can create the vicious cycle of poverty carrying impotency to contribute in national economy.

The widespread use of formalin, on fish preservation and other nutriments is posing a threat to public health. Formalin is one of the most effective and widely used compounds in fish culture for therapeutic and prophylactic treatment of fungal infection and external parasites of fish and fish eggs, but use of formalin in preservation of fish can cause severe health hazards. To meet up emerging demand, importation from neighboring countries significantly grab the fish trading encountered by formalin treatment prior to import contemplating extended shelf life. Ingested Formalin even in small quantities is harmful, because once it contacts the body cells, it kills the cells. Undoubtedly, formalin ingestion paves the way for 
deleterious effects on almost all systems of the body leading less productivity influenced by economical entailment. Awareness rising among generals regarding severity of formalin misuse with different aspects through the country can facilitate protection aiming for national security. The objective of this study was to determine the fish marketing strategy in Bangladesh with the practice of formalin considering the effect on health.

\section{FORMALIN AND ITS EFFECT ON HEALTH}

Formalin is a solution made up of $37 \%$ formaldehyde by weight, which is stabilized by the addition of methanol. If used in sufficiently low quantities, it does have legitimate commercial uses, for example, to prevent bacterial growth in fish farms. Nonetheless, in larger doses or with extended exposure, formaldehyde is considered to be toxic and cancer causing. Formalin is irritating, corrosive and toxic and absorbed from all surfaces of the body. Although the short-term health effects of formaldehyde exposure are well known, less is known about its potential long-term health effects. Regular consumption of formalin-laced fish increases chance of malignancy and neurological impairment or brain functions. The International Agency for Research on Cancer (IARC) says there was sufficient evidence for carcinogenicity in humans. Based on the available evidence, some of these expert agencies have evaluated the cancer-causing potential of formaldehyde. On 10 June 2011, the US National Toxicology Program formally described formaldehyde to be a known carcinogen. The most common result of chronic poisoning caused by formalin is damaged kidneys and cancer. Formalin may cause uncontrolled cell growth or cancer in stomach, lung and respiratory system if anyone consumes fish contaminated with it. A study showed mice exposed to formalin with concentration of 6 to 15 ppm for 2 years developed squamous-cell carcinoma in the nostril [3]. Formalin causes diverse histopathological changes indicating the destruction in the liver tissue and this destruction has direct relationship with the length of the exposure period [4]. It has a harmful effect on reproduction system by inducing oxidative stress [5],[6]. High consumption of formalin could cause damage to the cornea in the eyes and result in loss of vision. Formaldehyde causes inflammation of the linings of the mouth, throat and gastrointestinal tract and eventual ulceration and necrosis of the mucous lining of the gastrointestinal tract producing lesions in the parenchymatous organs [7]. Laboratory studies showed that exposure to formaldehyde could cause nasal cancer in rats. A cohort study of 11,039 textile workers performed by the National Institute for Occupational Safety and Health (NIOSH) also found an association between the duration of exposure to formaldehyde and leukemia deaths [8]. Table 1 shows the summery of negative effects using formalin.

Table 1. Effect of formalin treated fish consumption on health

\begin{tabular}{|c|c|}
\hline Exposure routes & Effect on human \\
\hline Carcinogenicity & $\begin{array}{l}\text { Formalin has the potential effect to cause cancer, repeated and } \\
\text { prolonged exposure increases the risk of cancers of the lung, } \\
\text { nasopharynx, oropharynx and nasal passage }\end{array}$ \\
\hline Reproductive health & $\begin{array}{l}\text { It has a harmful effect on reproduction system by inducing } \\
\text { oxidative stress. }\end{array}$ \\
\hline Skin (dermal) & $\begin{array}{l}\text { Prolonged and repeated contact with formalin could cause } \\
\text { numbness (lack of feeling) and a hardening or tanning of the } \\
\text { skin }\end{array}$ \\
\hline Eye contact & $\begin{array}{l}\text { Formalin solution splashed in the eye can cause in juries from } \\
\text { transient discomfort to severe such as loss of vision }\end{array}$ \\
\hline
\end{tabular}

\section{FORMALIN LACED FISH MARKETING IN BANGLADESH}

A number of studies done by the Bangladesh government showed that a significant percentage of fish which is imported from neighboring countries are contaminated with formalin. Large species, eminently imported rohu (Labeo rohita) are more susceptible to formalin poisoning from $42 \%$ to $70 \%$ encompassing 3.4 folds higher compared to small, locally produced one; therefore most of the city markets abundant with imported carps make the absolute intendment of happening. In Bangladesh for the first time formalin treated fishes were identified in 2006 during an operation against impure food by a mobile court led by a Metropolitan Magistrate. Different studies show strong evidence of the presence of formalin in fish.

The extent of formalin contamination is not entirely clear. Several studies have attempted to measure the intensity of the problem in Bangladeshi fish markets; however, their findings have differed substantially. Research undertaken and published in 2009 based on a study of four fish markets in Dhaka City

IJPHS Vol. 3, No. 2, June 2014 : $95-100$ 
found for malin contamination in only 50 of 800 fish sampled, or 6.25\%. The highest percentage was found in the Karwan Bazaar market. Large Rui and Katla, were the most commonly contaminated, although formalin use was also found in a number of other fish varieties including shrimp, Mrigal, and Kachki [9]. A somewhat later 2010 study of two markets and three grocery stores in Dhaka found that an alarming $42 \%$ of 100 fish sampled had been treated with formalin. These included $70 \%$ of sampled Rui, $50 \%$ of Katla, $40 \%$ of Mrigal, 50\% of Hilsa, and 0\% of Sharputi. Contamination across the five sites ranged from 20-60\% [10]. While percentages were not provided, a 2010 study in Mymensingh also found evidence of formalin in imported Rui and Katla but not in local varieties of the same fish. The findings were consistent across the five Mymensingh markets studied [11]. A 2012 study of five markets in Sylhet found formalin in 26 of 150 sampled fish, or $17.3 \%$. Again contamination occurred across the five markets, although it ranged from $6 \%$ to $26 \%$ of fish tested. Evidence of formalin was found in Rui, shrimp, and Katla, but not Mrigal or Hilsa [12]. These findings make clear that formalin is a common and even growing problem; however, they also suggest that it is perhaps not as pervasive as some media reports would suggest.

Formaldehyde levels in fish are high in imported rui fish coming from India and Myanmar. Both large and small species are affected by formalin treatment, where large carp species being consumed by 31\% of urban people [13] which were usually imported from India and Myanmar are found with higher formalin concentration in most of the retails markets. In contrast inland fresh fishes \& Small indigenous species are less formalin exposure. Extended shelf life of formalin treated rohu fish compared to fresh one stored in ice is only by 6 days, but considering the small profit in business, most of the traders use formalin as preservative purpose beyond considering its ethical aspects.

Having poor organoleptic characteristics in formalin treated fish [14]; price comprises a little difference with less potentiality compared with inland production. Though inland aquaculture account 39\% of total fish production, a major portions are being imported from neighboring countries prompts the risk for formalin treatment. Dhaka and Sylhet, two economically potent district of Bangladesh showed a comparative nomenclature on fish marketing, holding similarity on formalin practice signified by a slight epidemic with 17.3\% [13] in Sylhet come up to Dhaka with 6.25\% [4].Large species are more affected as to small one; intimated by both study zones taking in $10.25 \%$ and $13.3 \%$ estimating the affected rohu with $44 \%$ and $42.3 \%$ in Dhaka and Sylhet aside. Formalin treated small species comprising 2.25\% and 33.3\%, found in Dhaka \& Sylhet respectively.

Table 2. District based comparison of formalin treated fish in Bangladesh

\begin{tabular}{|c|c|c|c|c|c|}
\hline Zone & $\begin{array}{l}\text { Formalin treated } \\
\text { fish (\%) }\end{array}$ & $\begin{array}{l}\text { Formalin treated } \\
\text { large species (\%) }\end{array}$ & $\begin{array}{c}\text { Formalin treated } \\
\text { SIS (\%) }\end{array}$ & $\begin{array}{c}\text { Formalin treated } \\
\text { rohu (\%) }\end{array}$ & $\begin{array}{c}\text { Formalin treated } \\
\text { catla (\%) }\end{array}$ \\
\hline Dhaka & 6.25 & 10.25 & 2.25 & 44 & 22 \\
\hline Sylhet & 17.3 & 13.3 & 33.3 & 42.3 & 19.2 \\
\hline
\end{tabular}

Table 3. Formalin treated fish marketing by year in Dhaka City

\begin{tabular}{|c|c|c|c|c|c|}
\hline Year & $\begin{array}{c}\text { Formalin treated } \\
\text { fish (\%) }\end{array}$ & $\begin{array}{c}\text { Formalin treated } \\
\text { rohu(\%) }\end{array}$ & $\begin{array}{c}\text { Formalin treated } \\
\text { catla(\%) }\end{array}$ & $\begin{array}{l}\text { Formalin treated } \\
\text { fish in jatrabari } \\
\text { bazaar }(\%)\end{array}$ & $\begin{array}{l}\text { Formalin treated } \\
\text { fish in kawran } \\
\text { bazaar (\%) }\end{array}$ \\
\hline 2009 & 6.25 & 44 & 22 & 20 & 46 \\
\hline 2011 & 42 & 70 & 50 & 40 & 60 \\
\hline
\end{tabular}

\section{WORLDWIDE SCENARIO OF FORMALIN LACED FISH MARKETING}

A recent study by Badan Pengawas Obat dan Makanan (BPOM), Indonesia’s department controlling and surveying food and drug, has found that a section of dishonest traders are using formalin widely in preservation of food items, including fish. ${ }^{15}$ Last December (2005), BPOM performed a laboratorium test of 161 samples of sea products (including fish, squid, shrimp, oyster, dried salted fish / squid), tofu, and wet noodles from 6 cities at Lampung, South Sumatra. The test showed 64 samples were found positive containing formalin. Furthermore, BPOM also performed a simple experiment on the positive samples in attempt to remove the formalin content. These products were washed thoroughly and boiled in water with a temperature of $80^{\circ} \mathrm{C}$ for 5 to 10 minutes. The formalin level was reduced but not fully removed. So the conclusion, once formalin is added, it can not be removed. Fishmongers in Axim in the Nzema East Municipality use the preservative agent mainly formalin to store tuna and other large fishes in order to remain fresh for a long period [15]. Some fishermen in Sekondi-Takoradi have condemned the alleged use of Formalin by their colleagues to preserve fish at Axim in the Nzema East Municipality of the Western Region [16]. Formalin treatment increases the shelf life of the fish which takes about a week to reach Punjab from Andhra Pradesh, hence it is often used to illegally preserve perishable food items like fish and fruit [17]. In 
Tanzania, using of formalin to store fish in Dar es Salaam, Lindi and Coast regions is widespread [18]. Surveys carried out by the association in sabah, malaysia, it was found that almost $80 \%$ of consumers in Sabah in both rural and urban areas are eating formalin-tainted fish [19]. Fish retailers and wholesalers in Sri Lanka are using formalin to prevent fresh fish from getting spoilt [20]. Some vendors and dealers had illegally used formaldehyde to preserve fish in china [21]. Formalin is being used in parts of Ghana to preserve tuna and other large fish in Ghana.

\section{ECONOMICAL EFFECT OF FORMALIN USE IN FISH MARKETING}

The role of fisheries sector in the development of agro-based economy of Bangladesh is very important and promising. The fisheries sector contributes $5.10 \%$, of the country's export earnings, $4.91 \%$ of its GDP and provides $63 \%$ of the national animal protein consumption. Fish and fishery products are the country's third largest export commodity contributing 5.10\% of its exchange earnings, in 2002-2003 Bangladesh earned US\$ 324 million of which shrimp alone contributed $72 \%$ of the total by quantity and $89 \%$ by value. It is claimed that the total fish production has increased significantly over the last few decades but it is not sufficient to meet up the growing demand of the country. As a result imported fishes from neighboring countries enter in the domestic market and it was reported that more than 80 metric ton of fish and fishery products enter into Bangladesh every day through the Teknaf border from Myanmar. Available reports suggest that formalin is sometimes added or sprayed to the fishes by the fish traders while transporting to domestic marketing chain to prevent spoilage and increase shelf life. Studies conducted at different markets in Dhaka city and Mymensingh Sadar rationalizes the incidence of adding formaldehyde/formalin to fishes especially imported from neighboring countries. Formalin laced foods are harmful to public health and the people, using them for a long time, might suffer from respiratory and neurological problems, along with troubles from cancer, liver cirrhosis, kidney, lung, allergy, asthma and other health hazards. Mainly in the city's wholesale kitchen markets, many traders collect fishes across the areas outside this city and before selling them to the small traders of different city areas, they have to preserve the items more than a day in their stores. The small traders often have to store their items one or two days long before selling them to the retail shoppers. So they use chemical preservatives to keep stocked fish items fresh. Fish contaminated with formalin is a common word that lurks in the fearful minds of shoppers at fish markets of Bangladesh now. The irony of the situation is that the use of formalin affects our health as well as businessman affiliated with formalin culture. One can not deny that a healthy and well feed citizen is better suited for increase productivity as part of their workforce, but formalin practice can be accountable for threatening the productivity beyond growth, development \& accomplishment. Besides, by offering a reliable product, traders and venders can increase their sales and their prices promoting better economy.

\section{ROLE OF RELEVANT AGENCIES IN PROTECTION}

Governments' inadequate monitoring in markets frustrates most citizens. Some customers and small fish traders lament that the government's monitoring issue is confined only to the busy fish markets and not during other times and areas, especially during different stages of fish trading. The ministry of fisheries and livestock (MoFL) said recently that the government has taken initiatives at imparting training programmes to raise awareness against use of formalin to around 40 thousand people related to fish cultivation and trading. Clearly, improved regulations and enforcement have to be part of the solution, and recently the food ministry has proposed consolidating inspections under one agency. Nonetheless, to date the governmental response has clearly fallen short. In fact, the problem is so extensive that a strong regulatory response might be unrealistic given the current limitations of Bangladesh's regulatory institutions. Therefore, it is necessary to ask if there are other complementary and non-governmental solutions to such market failures. Government should take steps to raise awareness among fish traders for not using formalin on fish as formalin does not harm only the general shoppers but also these threaten the family members of the fish traders who consume such fish.

\section{CONCLUSION}

Formalin practice has been going on unabated in fish markets of Bangladesh due to some unscrupulous trader's ill intentions and also indulgence by government negligence to check the trends. Despite having detrimental effects on human health; this imminent contingency has been come about with an alarming rate inducing great economical losses be confronted by commonality. Contemplative concern from corresponding authorities must be enforced prioritizing on the ultimate punishment to the shameless traders ensuring the increased acquaintance among community. 


\section{REFERENCES}

[1] Formalin fear grips city dwellers, “The daily Star, 2009. http://www.thedailystar.net/newDesign/newsdetails.php?nid=104480.

[2] Roos N., Islam M. M., “Thilsted SH. Small Indigenous Fish Species in Bangladesh: Contribution to Vitamin A, Calcium and Iron Intakes”, J. Nutr, vol/issue: 130(11), pp. 4021S-4026S, 2003.

[3] http://indiatoday.intoday.in/story/mortuary-chemical-formalin-used-on-your-fish/1/152653.html.

[4] Brown K. G., "Risk assessment of laboratory rats and mice chronically exposed to formaldehyde vapors", Risk Anal, vol/issue: 5(3), pp. 171-80, 1985.

[5] Selman Cikmaz, Tunc Kutoglu, Recep Mesut, "Effect of formaldehyde inhalation on rat livers: A light and electron microscopic study”, Toxicol Ind Health, vol/issue: 26 (2), pp. 113-119, 2010.

[6] Dangxia Zhou, Jing Zhang, Haixu Wang, “Assessment of the potential reproductive toxicity of long-term exposure of adult male rats to low-dose formaldehyde”, Toxicol Ind Health, vol/issue: 27(7), pp. 591-598, 2011.

[7] Hai-xu Wang, Xiao-yan Wang, Dang-xia Zhou, Lie-rui Zheng, Jing Zhang,Yong-wei,et_al, “Effects of low-dose, long-term formaldehyde exposure on the structure and functions of the ovary in rats", Toxicol Ind Health, vol/issue: 29(7), pp. 609-615, 2013.

[8] Pinkerton LE, Hein MJ, Stayner LT, “Mortality among a cohort of garment workers exposed to formaldehyde: An update”, Occupational Environmental Medicine, vol. 61, pp. 193-200, 2004.

[9] Emdadul Haque, A.B.M. Mohsin, “Intensity of Formalin Use for Consumable Fish Preservation in Dhaka City”, Bangladesh. J Fisheries Int., vol/issue: 4(3), pp. 52-54, 2009.

[10] Riaz Uddin, Moin Ibna Wahid, Tasbira Jasmeen, Naz Hasan Huda, Kumar Bishwajit Sutradhar, "Detection of Formalin in Fish Samples Collected from Dhaka City, Bangladesh”, Stamford J PharmaSci., vol/issue: 4(1), pp. 49-52, 2011.

[11] T yeasmin, M S Reza, M N A Khan, F H Sikha, M Kamal, "Present status of marketing formalin treated fishes in domestic markets at mymensingh district in Bangladesh”, Int.J.bioRes., vol/issue: 1(4), pp. 21-24, 2010.

[12] M. M. Rahman, S. A. Ahmed, M. M. Hosen, A. K. Talukdar, "Detection of formalin and quality characteristics of selected fish from wet markets at sylhet city in Bangladesh”, Bangladesh Res Pub J, vol/issue: 7(2), pp. 161-169, 2012.

[13] Martin H. Fischer, “The Toxic Effects Of Formaldehyde And Formalin”, J of Exp Med, vol/issue: 6(4-6), pp. 487518, 1905.

[14] Belton B., Karim M., Thilsted S., Murshed-E-Jahan K., Collis W., Phillips M., "Review of aquaculture and fish consumption in Bangladesh”, Studies \& Reviews 2011-53. The WorldFish Center. 2011.

[15] http://gbcghana.com/?id=1.1408887.

[16] http://www.modernghana.com/news/467224/1/fishermen-condemn-formalin-use.html.

[17] http://indiatoday.intoday.in/story/mortuary-chemical-formalin-used-on-your-fish/1/152653.html.

[18] http://www.jamiiforums.com/jukwaa-la-siasa/48563-formalin-and-the-fish-we-eat.html.

[19] http://www.thestar.com.my/News/Nation/2013/01/20/Sabah-anglers-Chemical-used-to-preserve-fish-sold-inmarkets.aspx.

[20] http://www.poandpo.com/business-as-usual/fish-in-sri-lanka-kept-in-formalin-31-7-2013/.

[21] http://www.infoyu.net/NewsCenter/QualityControl/08-10-15-97.html.

\section{BIOGRAPHIES OF AUTHORS}

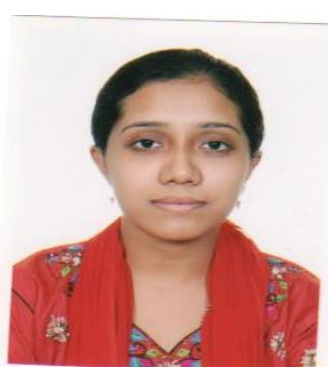

I am Shatabdi Goon. I have completed my bachelor degree with CGPA 4(out of scale 4) under the department of Nutrition and Food Engineering, Daffodil International University. I completed my secondary school certificate with GPA 5 and got gold medal for the achievement. I also got GPA 5 in my higher secondary school certificate. I got government scholarship in class five as well as in eight. I am very much interested in research. I have already published three of my research paper in 3 distinct international journals. I have also got chance participating in International conference on public health which had been held in Thailand. I am active member of Daffodil International University health club and doing different workshops and seminars regarding health and nutrition. I have taken the initiative to improve the micronutrient status of pregnant women and done some population base survey revealing the current status of malnutrition among pregnant women. I wish to work in nutrition sector aiming to improve the overall health status of Bangladeshi population. 


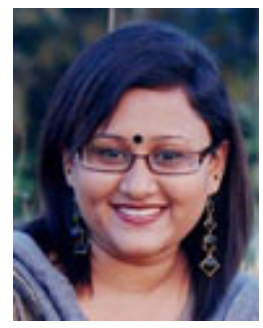

I am Munmun Shabnam Bipasha. I have completed my bachelor and masters degree under the department of Economics, Jahangirnagar University. I am very much interested in research. I have already published Two of my research paper in 2 distinct international journals. I have also got chance participating in International conference on public health which had been held in Thailand.

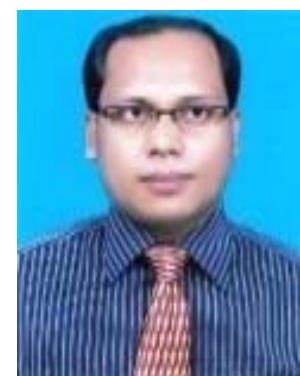

I am Md.Saiful Islam. I have completed my Master degree with CGPA 3.70 (out of scale 4) and also bachelor degree with first class first under the department of Applied nutrition \& food technology. Islamic University. I completed my secondary school certificate with GPA 3.69 I also got GPA 3.60 in my higher secondary school certificate. I got government Merit scholarship in Both Masters and Bachelor degree. I am very much interested in research. I have already published one of my research paper in 1 distinct international journals. I have also got chance participating in international conference on public health which had been held in Thailand. I am active member of Islamic University health club and doing different workshops and seminars regarding health and nutrition. I have taken the initiative to improve the micronutrient status of pregnant women and done some population base survey revealing the current status of malnutrition among pregnant women. I wish to work in nutrition sector aiming to improve the overall health status of Bangladeshi population. 